\title{
The Influence of Gender and Culture on Transformational and Transactional Leadership Style
}

\author{
Yuhanis Che Hassan, Mohamad Hisyam Mohd. Hashim \\ Faculty of Technical and Vocational Education, Universiti Tun Hussein Onn Malaysia, Parit Raja, Batu Pahat, Johor, Malaysia
}

Email Address:

yuhanis_chehassan@yahoo.com (Y.C.Hassan), mhisyam@uthm.edu.my (M. H. M. Hashim)

\section{To cite this article:}

Yuhanis Che Hassan, Mohamad Hisyam Mohd. Hashim. The Influence of Gender and Culture on Leadership Style in Faculty of Technical and Vocational Education. International Journal of Vocational Education and Training Research. Vol. 1, No. 1, 2015, pp. 10-15.

doi: 10.11648/j.ijvetr.20150101.13

\begin{abstract}
The aim of this study is to investigate the different leadership styles of the workers and the influence of gender and culture on the leadership styles of the workers in Faculty of Technical and Vocational Education (FPTV), Universiti Tun Hussein Onn Malaysia (UTHM). These studies concentrate on two leadership styles which are transformational leadership and transactional leadership. Transformational leadership and transactional leadership styles have attracted the interest of many researchers in recent time. While some believe that they are the same, others believe they are different. This paper gives an introductory perspective into the difference between transformational and transactional leadership in context of the influence of culture on leadership style in FPTV. Selected sample consist of 123 staff from all department in FPTV. In order to implement this study, questionnaire has been used to collect data from respondent. The raw data obtained was analyzed quantitatively by SPSS (Statistical Package for Social Science) version 20.0. The data was analyzed using descriptive analysis and scoring. The study found that in FPTV, the leader is prone to be more transformational than transactional. Although they are conceptually different, some elements of transactional leadership exist in transformational leadership. It also shows that there is no gender influence upon leadership styles. In contrast, culture exerts a little more impact on leadership style in FPTV.
\end{abstract}

Keywords: Leadership, Gender, Culture, Transformational Leadership, Transactional Leadership

\section{Introduction}

Leadership is perhaps one of the most important aspects of management [1]. This is because leadership is a major factor which contributes immensely to the general wellbeing of organizations and nations. Organizations such as General Electric and Chrysler had been turned around from the brink of bankruptcy to become two of the world's most profitable organizations through the effective leadership of [2]. Great nations like the United State of America, Britain, France and India are some of the most prominent nations in the world today on the wings of effective leadership [1]. This is because leaders in organizations and nations make things happen. This paper defines leadership as the process of influencing groups to achieve goals, while a leader is someone who can influence others [1,2,3]. Several theories have and are being put forward to explain leadership effectiveness. Two of the most prominent leadership theories are Transformational and Transactional leadership theories. Since the late 1980 s, theories of transformational leadership have been ascendant, while transformational leadership have been proposed by several theorists, including [4]. Although most author agree that Transformational and Transactional leadership are different in concept and in practice, many authors believe that transformational leadership significantly augments transactional leadership, resulting in higher levels of individual, group, and organizational performance $[5,6]$. Others believe that Transactional leadership is a subset of transformational leadership [1].

Due to gender and cultural differences, managers probably lead their companies in different ways even in similar industries. From a gender perspective, some researchers indicate that male managers have a more transactional leadership style, while female managers' leadership style could be described more as transformational [7]. Others show that female managers see themselves and their superiors as androgynous; whereas male managers see themselves as masculine or feminine [8]. On the contrary, some researchers report that female managers lead companies in ways that are more similar than different to 
men in male-dominated industries [9]. This argument reversely indicates that a company's management practices are somewhat influenced by the nationality of the leaders rather than the gender differences [10]. We observe that there are various opinions toward the same issues among the researchers. Some show that the different leadership styles result from the different cultural contexts.

\subsection{Problem Statement}

Over the past 20 years, researchers of women leaders and managers have built a large body of literature addressing three fundamental questions: Can women be leaders? Do male and female leaders differ in their behavior and effectiveness in organizations? Why do so few women leaders reach the top? [11]. Currently, a great deal of information exists about gender-related issues. For example, information exists about gender roles, sex stereotypes in advancing to the top of organizations referred to as the 'glass-ceiling' effect [11,12] and situations in which leader consciously define their organizational culture from the very beginning through leadership qualities, traits, and styles common to their gender. Very little is known about how gender directly or indirectly influences the culture of an organization when the culture is already subconsciously in place. To ensure that organization will achieve their objectives, it is imperative to understand any influences that would affect organizational culture. In other words, because the alignment of organizational culture with the goals of the organization is extremely instrumental in the success of any organization [14], it is important to understand whether the gender of the business owner has any impact on organizational culture.

From the literature review and discussion, we know that most of the related studies focus on either the relationship between leadership and gender, or the relationship between leadership and culture. On the other hand, research on the influence of gender and culture on leadership in FPTV, UTHM is limited. [15] also recommended more research into gender characteristics and cultural orientations, particularly Hofstede's dimensions, in order to gain a greater understanding of the influence of culture on leadership. This present research will hopefully can find the new light on that issue.

\subsection{Purpose}

The main purposes of this research are as follows:

Firstly, researcher broadens the current framework of research on two different leadership styles: transformational and transactional, to empirically evaluate managers' leadership styles in FPTV, UTHM. Secondly, researcher tries to analyze and identify the influence of gender and culture on leadership styles. Finally, researcher attempt to build our own model concerning the correlation between gender and leadership styles, and the relation between culture and leadership styles, and hopefully it can be generalized and applied in different cultural context other than institution organization.

\section{Literature Review}

\subsection{Leadership}

A person who leads a group of people towards a common goal, is knows as a leader [16]. The leader influences his group members to accomplish the specified objectives and the way in which the leader handles his followers is known as leadership style [17]. According to [18], leadership is "the art or process of influencing people so that they will strive willingly towards the achievement of objects". [19] point is that, leadership is an act of influencing subordinates to accomplish organizational goals through authority. In the other words, leadership is a process of interaction between leaders and followers where the leader attempts to influence followers to achieve a common goal $[11,19]$. According to [20], previous studies on leadership have identified different types of leadership styles which leaders adopt in managing organizations. Among the more prominent leadership styles are [21] transactional and transformational leadership styles.

\subsection{Gender}

Gender refers to the distinctive culturally created qualities of men and women apart from their biological differences [22]. It is possible that males and females might lead from different perspectives. [23] claim that "Current psychological research on leadership and team interaction suggests that men and women exhibit different leadership styles and interpersonal communication styles in a variety of small-group situations from student problem- solving situations to industry and community situations". According to [24], "women executives are much more likely than males to be a department head or to fill some other staff position, whereas men are much more likely to be a chief executive officer (CEO), chief operating officer (COO), president, or vice president". [25] states that "Rather than intentional acts of bias, second-generation gender biases reflect the continuing dominance of traditionally masculine values in the workplace". According to common perception, women are more emotional and less competitive than men. For example, some authors have written that "Women are significantly more risk averse, tend to be less overconfident and behave less competitively oriented" [26]. Furthermore, women are very similar to men in their leadership styles, but are often higher in the supporting role [27]. [28] claimed that in small groups, men focused somewhat more than women did on the strictly task-oriented aspects of group process, and women focused somewhat more than men on the interpersonally oriented aspects. [29] analyzed 162 studies and showed that when formal leadership positions were not being held, women used a more participative and inclusive style of leadership and men were more likely to use a directive, controlling style. 


\subsection{Culture}

[30], culture consists of various levels, since almost everyone belongs to a number of different groups and categories at the same time, and every group or category of people carries a set of common mental programs that constitutes its culture. There are four cultural dimensions which is power distance, collectivism versus individualism, femininity versus masculinity and uncertainty avoidance.

Power distance described the extent to which inequalities were accepted among the people of a society. In countries with high power distance, people accepted and expected differences in power among them, whereas in countries with low power distance, the majority expected that the differences in power should be minimized.

Collectivism versus Individualism described the degree to which individuals in a society were integrated into groups. In an individualistic society, the ties between individuals were loose. People were supposed to take care of themselves and their immediate families. In a collectivistic country, people were described as living within a tight social framework.

Femininity versus Masculinity reflected the distribution of roles between sexes that different societies exhibited in different ways. [31] analysis revealed that the dominant values of people in a masculine society were assertive and competitive, whereas members of a feminine culture valued more nurturing, caring, and modesty.

Uncertainty avoidance indicated the extent to which people in a society feel threatened by unpredictable or unknown situations and thus "try to avoid these situations by providing greater career stability, establishing more formal rules... and believing in absolute truths and the attainment of expertise" [32].

Hofstede's cultural framework, according to [33] provided "the best there is" of a conceptual benchmark for understanding culture in many societies or countries. The model not only showed the significant relationships between its dimensions and several areas of general management, for example for motivation systems and for decision making, but also its relationships with leadership behaviors [34].

\subsection{Transformational Leadership}

Transformational leadership is extremely important for the smooth running and progress of organizations. According to Burns [21], transformational leadership "occurs when one or more persons engage with others in such a way that leaders and followers raise one another to higher levels of motivation and morality." It differs, however from earlier conceptualizations of charisma as the leader also demonstrates individualized consideration and intellectual stimulation. A transformational leader encourages and supports individual members of the group [35]. Howell and Avolio [6] studied 78 managers to show that transformational leaders were associated with a higher internal locus of control and significantly and positively contributed to the achievement of business-unit goals.

[2], a transformational leader is a person who stimulates and inspires (transform) followers to achieve extraordinary outcomes. He/she pay attention to the concern and developmental needs of individual followers; they change followers' awareness of issues by helping them to look at old problems in a new way; and they are able to arouse, excite and inspire followers to put out extra effort to achieve group goals. Transformational leadership enhances the motivation, morale, and performance of followers through a variety of mechanisms. These include connecting the follower's sense of identity and self to the project and the collective identity of the organization; being a role model for followers that inspires them and makes them interested; challenging followers to take greater ownership for their work, and understanding the strengths and weaknesses of followers, so the leader can align followers with tasks that enhance their performance [36]. As modeled by Bass, transformational leadership is comprised of four central components: charisma, inspiration, individualized consideration, and intellectual stimulation.

\subsection{Transactional Leadership}

Transactional Leadership, also known as managerial leadership, focuses on the role of supervision, organization, and group performance; transactional leadership is a style of leadership in which the leader promotes compliance of his followers through both rewards and punishments [36]. Bass [37] states that transactional leadership is built on reciprocity. The relationship between leaders and their followers develops from the exchange of some reward, such as performance ratings, pay, recognition, and praise. It involves leaders clarifying goals and objectives, and communicating to organize tasks and activities with the cooperation of their employees to ensure that wider organizational goals are met. Such a relationship depends on hierarchy and the ability to work through this mode of exchange.

According to [4], transactional leadership is based on the exchange process where the leader administers rewards and sanctions. The leader and follower agree, explicitly or implicitly, that desired follower behaviors will be rewarded, while undesirable behaviors will draw out punishment. Potential rewards include an increase in salary, promotions, and more benefits. Conversely, penalties may include pay cuts, demotions, and terminations. Based on this, one could argue that transactional leadership behaviors do not even qualify for a "true" leadership label [38]. Since it is based on exchange, transactional leadership does not seek to motivate followers beyond the level that is required to avoid punishment or gain extrinsic rewards. Transactional leadership is comprised of two fundamental dimensions: contingent reward and management-by-exception.

\section{Methodology}

One of the goals that research methodology is to find solution for each research question. This methodology is a guide for researcher to gets the input or data that needed related with the research objective [39]. Research methodology that conducted is one method to answer the 
research question and involve quantitative method in the form of reviews or questionnaire. This study use review descriptive methods to answer the research question. The instrument that researchers use in this study to get the data and information about this study is questionnaires. The questionnaires is one of the popular and effective method because easy to manage and indirectly the data obtained also easy to process and analyzed. The questionnaire focused to the workers from all departments in Faculty of Technical and Vocational Education, FPTV, at Universiti Tun Hussein Onn Malaysia, UTHM.

\subsection{Sample and Population}

Research population comprises from the entire worker in Faculty of Technical and Vocational Education, FPTV at UTHM. About 123 staff that identified as research population.

\subsection{Questionnaire}

The item in the questionnaire that use in this study developed in keeping with the objective and research question. Questionnaire in this research is divided into three section that is section A, section B and section C. Item in section A have been built by researcher, while section $B$ and $C$ is adapted and modified from few previous study. Below is a section that contained in the questionnaire:

- Section A

Section A is item about background of respondents. Four general questions were formulated in order to get some information about respondents, including their age, gender, race, and positions.

- Section B

There were 24 questions concerning leadership styles in the questionnaire. This part of questionnaire was based on a modified version of the Multi-Factor Leadership Questionnaire (MLQ) developed by Bass and Avolio (1998). The MLQ is a well-known instrument used to measure perceived frequency of transformational and transactional leadership behavior.

- Section C

There were 16 questions concerning cultural dimensions were presented. This part was based on Hofstede's Theory of Cultural Dimensions. There are four dimensions of Hofstede's theory which is Power Distance, Individualism/ Collectivism, Masculinity/ Femininity, and Uncertainty Avoidance.

After all questionnaire has been collected, information that be given by respondent will be analyze by Statistical Package for Social Science (SPSS) version 20.0 for windows. After that, discussion, conclusion and suggestion about this study will be done based on result from conducted analysis.

\section{Result}

\subsection{Demography Respondent}

The demographic characteristics of respondents are reported in Table 1.
Table 1. Respondents' Profiles.

\begin{tabular}{llll}
\hline Variable & Characteristic & Frequency & Percentage \\
\hline \multirow{3}{*}{ Age } & $20-29$ & 7 & 7.6 \\
& $30-39$ & 34 & 37.0 \\
& $40-49$ & 30 & 32.6 \\
\multirow{3}{*}{ Gender } & 50 and above & 21 & 22.8 \\
& Male & 36 & 39.1 \\
\multirow{3}{*}{ Race } & Female & 56 & 60.9 \\
& Malay & 86 & 93.5 \\
& Chinese & 6 & 6.5 \\
& Clerical & 5 & 5.4 \\
& Lower level of Management & 28 & 30.5 \\
& Middle level of Management & 47 & 51.1 \\
& Top level of Management & 12 & 13.0 \\
\hline
\end{tabular}

\subsection{Research Question 1}

What characterize the leadership styles in FPTV?.Are they transformational or transactional?

In order to find out what kind of leadership style in FPTV managers adopt, researcher formulated 15 questions to test transformational leadership style and 9 questions to test transactional leadership style. The two kinds of leadership styles - transformational leadership style and transactional leadership style - were respectively tested by their characteristics. The former has the following characteristics: Idealized Influence Inspirational Motivation, Intellectual Stimulation, Individualized Consideration, and Risk Acceptance; whereas, the latter has the characteristics of Contingent Reward, Management-by-Exception, and Laissez Faire.

Based on SPSS analysis, researcher analyzed the responses from the entire worker in Faculty of Technical and Vocational Education, FPTV at UTHM, finding that the leaders from all departments on that faculty tend to be more transformational than transactional. The result was showed that the means range from 3.26 to 6.31 . Comparison of means suggests that the characteristic of leadership style in FPTV is toward transformational leadership style with inspirational motivation dimension. Standard deviations are closed to one which is at an acceptable level. The results are show in Table 2.

Table 2. Mean Responses on the Characteristic of Leadership Style.

\begin{tabular}{lll}
\hline Dimensions & Mean & Std. Deviation \\
\hline Idealized Influence & 4.9825 & 0.66192 \\
Inspirational Motivation & 6.3050 & 0.75482 \\
Intellectual Stimulation & 4.6250 & 0.90017 \\
Individualized Consideration & 4.4075 & 0.87264 \\
Risk Acceptance & 3.6878 & 0.82925 \\
Contingent Reward & 5.4560 & 0.83880 \\
Management-by-Exception & 3.2575 & 0.85504 \\
Laissez Faire & 4.9043 & 0.78588 \\
\hline
\end{tabular}




\subsection{Research Question 2}

Which element - gender or culture - exerts a more important impact on the leadership styles in FPTV, UTHM?

\subsubsection{Result of Gender Influence on Leadership Styles}

Table 3. Comparison of Transformational leadership between Males and Females (Means and Significances).

\begin{tabular}{llll}
\hline Transformational & $\begin{array}{l}\text { Males } \\
\mathbf{3 6})\end{array}$ & $\begin{array}{l}\text { Females } \\
(\mathbf{N}=\mathbf{5 6})\end{array}$ & $\begin{array}{l}\text { Significance } \\
\text { (2-tailed) }\end{array}$ \\
\hline Idealized Influence & 4.61 & 4.50 & .523 \\
Inspirational Motivation & 4.83 & 4.66 & .329 \\
Intellectual Stimulation & 4.70 & 4.45 & .157 \\
Individualized Consideration & 4.65 & 5.00 & .000 \\
Risk Acceptance & 3.91 & 3.97 & .783 \\
Overall & 4.54 & 4.46 & .570 \\
\hline
\end{tabular}

Table 4. Comparison of Transactional leadership between Males and Females (Means and Significances).

\begin{tabular}{llll}
\hline Transactional & $\begin{array}{l}\text { Males }(\mathbf{N}= \\
\mathbf{3 6})\end{array}$ & $\begin{array}{l}\text { Females } \\
(\mathbf{N}=56)\end{array}$ & $\begin{array}{l}\text { Significance } \\
\text { (2-tailed) }\end{array}$ \\
\hline Contingent Reward & 4.30 & 4.33 & .899 \\
Management-by-Exception & 3.99 & 4.08 & .658 \\
Laissez Faire & 2.43 & 2.21 & .117 \\
Overall & 3.57 & 3.79 & .235 \\
\hline
\end{tabular}

In an independent t-test, researcher tends to assess whether the self-reported leadership styles of female leaders differ from those of male leaders. The results of are shown in Table 3 and Table 4. The finding suggests that the leadership style emphasized most by both male and female leaders is transformational leadership style. For the male samples, the overall mean value of transformational leadership is 4.54 , and the female have the score of 4.46 in transformational part. Correspondingly, both female and male leaders scored lower on transactional leadership style with the mean value of 3.57 and 3.79. The rank order of leadership styles are the same for both male and female leaders.

\subsubsection{Result of Culture Influence on Leadership Styles}

Table 5. Correlations Cultural Dimensions and Leadership styles.

\begin{tabular}{llll}
\hline \multicolumn{2}{l}{ Cultural Dimension } & $\begin{array}{l}\text { Transformationa } \\
\text { I Leadership }\end{array}$ & $\begin{array}{l}\text { Transactional } \\
\text { Leadership }\end{array}$ \\
\hline \multirow{2}{*}{ Power } & Pearson & $-.247\left(^{*}\right)$ & .106 \\
Distance & Correlation & & \\
& Sig. (2-tailed) & .019 & .319 \\
& $\mathrm{~N}$ & 92 & 92 \\
& Pearson & -.056 & .084 \\
Collectivism & Correlation & & \\
& Sig. (2-tailed) & .600 & .431 \\
& $\mathrm{~N}$ & 92 & 90 \\
& Pearson & .161 & $.327(* *)$ \\
Femininity & Correlation & & .002 \\
& Sig. (2-tailed) & .129 & 90 \\
& N & 92 & .056 \\
& Pearson & .141 & .603 \\
Uncertainty & Correlation & & 90 \\
Avoidance & Sig. (2-tailed) & .186 & \\
& N & 90 & \\
\hline
\end{tabular}

** Correlation is significant at the 0.01 level (2-tailed).

* Correlation is significant at the 0.05 level (2-tailed).
As stated before, both males and females in FPTV are alike in leadership styles, indicating there is no gender influence on leadership styles. Similarly, there is a very slight impact of culture upon leadership styles; that is to say, the three cultural dimensions which are Uncertainty Avoidance, Collectivism/ Individualism and Femininity /Masculinity have no correlation with leadership styles from statistical perspective. Only the dimension of Power Distance with a negative correlation value shows that managers in countries with small power distance tend to use a more transformational leadership. To sum up, compared to the gender element, culture exerts a little more impact on leadership style in FPTV, UTHM.

\section{Conclusion}

Result from this research suggests that leaders in FPTV are prone to be more transformational than transactional leadership. The study further shows the influence of gender and culture on leadership styles. With respect to the gender, both male leaders and female leaders tend to be transformational, indicating that there is no gender influence on leadership styles. As far as culture is concerned, Hofstede's four cultural dimensions are slightly correlated to leadership styles.

\section{References}

[1] Weihrich, H., Cannice, M.V. \& Koontz, H. (2008). Management. $12^{\text {th }}$.ed. New Delhi: Mc Graw Hill.

[2] Robbins, S. P. \& Coulter, M. (2007). Management. $9^{\text {th }}$ ed. London: Prentice- Hall.

[3] Cole, G. A. (2006). Management Theory and Practice. $6^{\text {th }}$ Ed. New York: Book Power.

[4] Bass, B. M. (1985). Leadership and performance beyond expectations. New York: Free Press.

[5] Bass, B. M. \& Avolio, B. J. (1994). Improving organizational effectiveness through transformational leadership. Thousand Oaks, CA: Sage.

[6] Howell, J. M. \& Avolio, B. J. (1993). Transformational leadership, transactional leadership, locus of control and support for innovation: Key predictors of consolidated-business unit performance. Journal of Applied Psychology, 7(1), 891-902.

[7] Rosener, J. B. (1990). Ways Women Lead. Harvard Business Review, 11(12), 119-125.

[8] Vinnicombe, S., Singh, V. \& Sturges, J. (2000). 'Making it to the Top in Britain', in R. J. Burke and M. Mattis (eds.), Women on Corporate Boards of Directors: International Challenges and Opportunities (Kluwer, Dordrecht), pp. 57-74.

[9] Gardiner, M. \& Tiggemann, M. (1999). Gender differences in leadership style, job stress and mental health in male- and female-dominated industries. Journal of Occupational and Organizational Psychology, 72(1), 301-315.

[10] Laurent, A. (1987). A Cultural View of Organizational Change. Working Paper 10: INSEAD, Fontainebleau. 
[11] Northouse, P. G. (2001). Leadership: Theory and practice. Thousand Oaks: Sage Publications.

[12] Hughes, R. L., Ginnett, R. C. \& Curphy, G. J. (2002). Leadership: Enhancing the lessons of experience. New York: McGraw-Hill.

[13] Manning, G.. \& Curtis, K. (2003). The art of leadership. New York: McGraw-Hill Higher Education.

[14] Kotter, J. P. \& Heskett, J. L. (1992). Corporate culture and performance. New York: The Free Press.

[15] Gibson, C. B. (1995). An investigation of gender differences in leadership across four countries. Journal of International Business Studies, 18(1), 255-279.

[16] Andrew J. D. (2009). Leadership. New York: Houghton Mifflin Company.

[17] Sheikh, A.G. (2001). Leadership Styles as Viewed by Secondary School Head Teachers of Lahore City. Hamdard University Karachi Pakistan: Master thesis.

[18] Adeyemi, T. O., Bolarinwa, R. (2013). Principals Leadership Styles and Student Academic Performance in Secondary Schools in Ekiti State, Nigeria. International Journal of Academic Research in Progressive Education and Development, 2(1), 187-198.

[19] Yukl, G. (2002). Leadership in Organizations. $5^{\text {th }}$. ed. New Jersey: Prentice Hall.

[20] Chen, K. J. \& Chen, S. I. (2008). Personal traits and leadership styles of Taiwan's higher educational institution in innovative operations. Journal of American Academy of Business, Cambridge, 12(2), 145-150.

[21] Burns, J. M. (1978). Leadership. New York: Harper \& Row.Brandser, G. C. (1996). "Women - the new heroes of the business world?". Women in Management Review, 11(2), 3-17.

[22] Winter. J, Neal. J. \& Waner. K. (2001). How male, female, and mixed-gender groups regard interaction and leadership differences in the business communication course. Business Communication Quarterly, 64(3) 43-58.

[23] Lantz. P. (2008). Gender and leadership in healthcare administration: 21 st century progress and challenges. Journal of Healthcare Management. 53(5), 291-301.

[24] Babcock. L. (2008). What happens when women don't ask? Negotiation, 11(96), 1-4

[25] Beckman. D. \& Menkhoff. L. (2008). "Will women be women?
Analyzing the gender difference among financial experts". Kyklos, 61(3), 364-384.

[26] Gregory, A. (1990). Three theoretical perspectives concerning women in management. Journal of Business Ethics, 9(1), 257266.

[27] Eagly, A. H. \& Karau, S. J. (1991). Gender and emergence of leaders: A meta analysis. Journal of Personality and Social Psychology, 60(1), 685-710.

[28] Eagly, A. H. \& Johnson, B. (1990). Gender and leadership style: A meta-analysis. Psychological Bulletin, 108(1), 233-256.

[29] Hofstede, G. \& Hofstede, G. J. (2005). Culture and Organizations: Software of the Mind. $2^{\text {nd }}$. ed. New York: McGraw-Hill.

[30] Hofstede, G. (1984). Culture's Consequences: International Differences in Work-Related Values. Beverly Hills: Sage Publications.

[31] Hofstede, G. (1995). Motivation, leadership, and organization: Do American theories apply Abroad?. 2 ${ }^{\text {nd }}$. ed. Boston: Irwin-McGraw-Hill

[32] Mead, R. (1998). International Management: Cross-Cultural Dimensions. Oxford: Blackwell Publishers.

[33] Muenjohn, N. \& Armstrong, A. (2001). Leadership and performance: the impact of the leadership behaviours of Australian expatriates on work outcomes. International Conference in Management Sciences. San Jose, Costa Rica: Universidad de Costa Rica. 550-557.

[34] Bass, B. M. (1998). Transformational leadership: industry, military and educational impact. New Jersey: Lawrence Erlbaum Associates.

[35] Warrilow. S. (2012). Transformational Leadership Theory The 4 Key Components in Leading Change \& Managing Change. Retrieved March 15, 2015, from $\mathrm{http}: / /$ EzineArticles.com/?expert=Stephen_Warrilow

[36] Bass, B. M. (1990). Bass \& Stogdill's Handbook of Leadership. (Rev. Ed.). New York: Free Press.

[37] Bryman, A. (1992). Charisma and Leadership in Organizations. London: Sage.

[38] Tuckman B. W. (1978). Conducting Educational Research. New York: Harcourt Brace Jovanovick, Inc.

[39] Kerlinger, F. N. (2000). Foundations of Behavioral Research. 4th Edition, New York: Holt, Rinehart and Winston. 